\title{
R on the side of caution
}

\author{
L. Baris · E. J. van den Bos
}

Accepted: 2 August 2021 / Published online: 22 September 2021

(C) The Author(s) 2021

A 52-year-old man known to suffer from dilated cardiomyopathy due to a mutation of the LMNA gene was admitted to the cardiac intensive care unit in cardiogenic shock. He had a cardiac resynchronisation device (CRT-D) programmed at a paced atrioventricular delay of $200 \mathrm{~ms}$ and a lower rate set at $80 \mathrm{beats} / \mathrm{min}$. The electrocardiogram at admission is shown in Fig. 1.

What rhythm is seen and how can the pacing activity be explained?

\section{Answer}

You will find the answer elsewhere in this issue.
Open Access This article is licensed under a Creative Commons Attribution 4.0 International License, which permits use, sharing, adaptation, distribution and reproduction in any medium or format, as long as you give appropriate credit to the original author(s) and the source, provide a link to the Creative Commons licence, and indicate if changes were made. The images or other third party material in this article are included in the article's Creative Commons licence, unless indicated otherwise in a credit line to the material. If material is not included in the article's Creative Commons licence and your intended use is not permitted by statutory regulation or exceeds the permitted use, you will need to obtain permission directly from the copyright holder. To view a copy of this licence, visit http://creativecommons.org/licenses/by/4.0/.

Fig. 1 Electrocardiogram at presentation
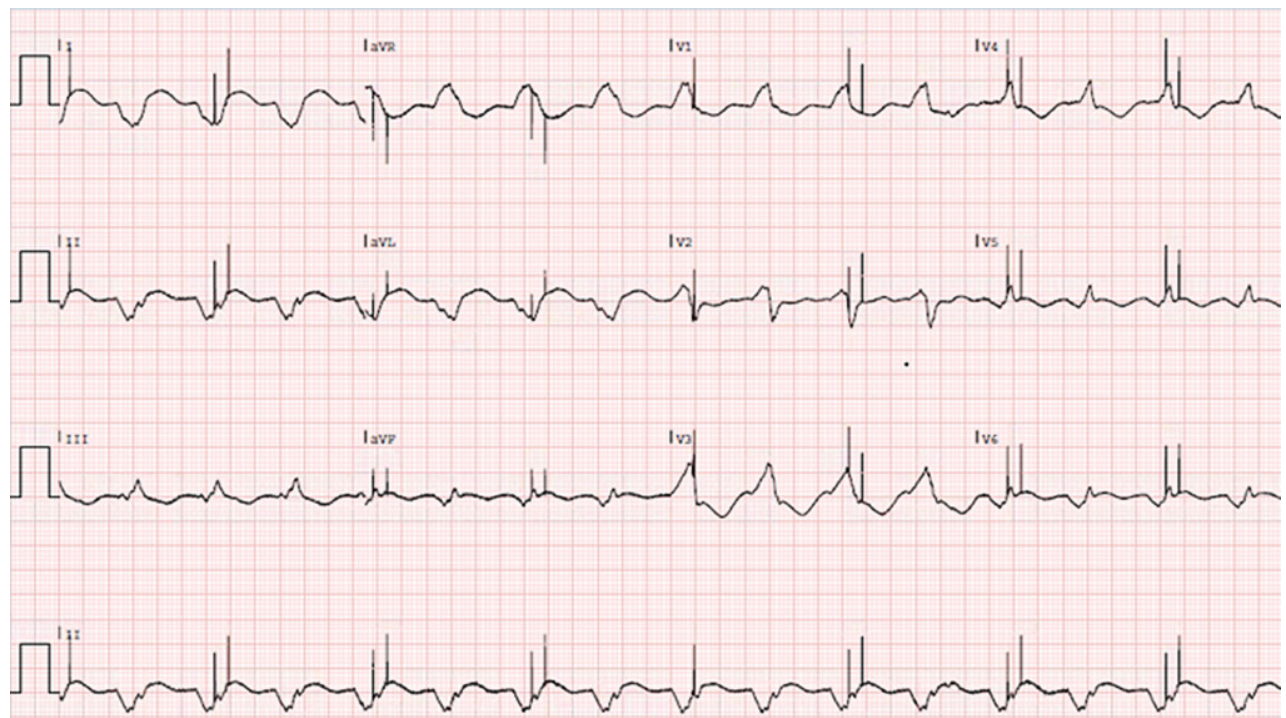

L. Baris · E. J. van den Bos $(\varangle)$

Albert Schweitzer Hospital, Dordrecht, The Netherlands

e.j.vanden.bos@asz.nl 